\title{
ERGOBERÇO $^{\circledR}$ (Ergonomics Crib)- Evalution of the prototype for a adaptation to safety's variables and comfort
}

\author{
Simone Caldas Tavares Mafra ${ }^{\mathrm{a},{ }^{*}}$, Vania Eugênia da Silva ${ }^{\mathrm{b}}$ and Luciana Aparecida de Oliveira ${ }^{\mathrm{b}}$ \\ ${ }^{\mathrm{a}, \mathrm{b}}$ Federal University of Viçosa, Department of Home Economics, Avenue Peter Henri Rolfs, s/n, 36570-000, \\ Vicosa, State of Minas Gerais, Brazil.
}

\begin{abstract}
The crib is the infantile furniture more mentioned in infantile accidents. In spite of the existence of several models, many of them are not appropriate to their users and considered insecure. The objective of this study was to structure the prototype of ERGOBERÇO ${ }^{\circledR}$, considering technical norms and evaluation in loco of the prototype through structured interview answered by the participants of the research. The prototype was evaluated as safer, resistant and comfortable than the crib used by the mothers and participant users of the study. The aspects with larger acceptance index were the movable grating and the compact base, defined for the users as facilitators of the use and attribute of safety of the prototype. Even the prototype having been very appraised and accept for the users, it will be necessary to restructure the prototype so that the same can still be adapted more the users' needs, being, besides insurance and comfortable, with compatible aesthetic pattern with the expectation of these.
\end{abstract}

Keywords: Product ergonomics; Children's Furniture; Cribs; Security; Comfort.

\section{Introduction}

The market of infantile of furniture offers a diversity of products, but studies have been evidencing that not always there is concern on the part of the industries with ergonomic beginnings and explanations to the final consumer, that, in compensation, not always worries in demanding safety, privileging the aesthetic subject to the detriment of the comfort and the safety, in consideration to the crib.

Among the infantile furniture, the crib is one of the ones that more needs that ergonomic approach, being considered safety's aspects and comfort, sometimes this kind of furniture that more related with accidents with babies and children. That die was discussed in research at hospitals in the State of Rio de Janeiro, Brazil, us which improved that the project flaws contributed to increase the indexes of accidents that happen in the strip of eight months to
04 years old. Many of those accidents can cause deaths or sequels. Among the occurrences, they stand out the falls, legs, arms and head arrested to the lateral grating and asphyxia (BRAZILIAN ASSOCIATION OF ERGONOMIA - ABERGO cited by [4].

In spite of the concern with insecure products for children to have increased in Brazil, there are no registrations, about this accidents involving crib, just isolated studies done by entities no government or representatives of the area of health [4].

With that, it is possible to notice that the safety's subject with the small children has been winning prominence, and the direct and indirect users of those products are understanding that you fail in the projects can produce different risks of accidents, as small pieces of furniture, for example, sharp songs, cutting parts, considering treating of crib, the situation becomes more critic due to the fact than, in the

Corresponding author. E-mail: sctmafra@ufv.br 
initial phase of the child's life. The child spends from 15 to 16 hours sleeping in the crib, and this situation increase the risks, and requests more attention with the product and use [2].

Fialho and Mafra,[3] they developed a study on safety and adequability of crib for children from 0 to 2 years old. To leave of that study, arose the proposal of structuring of the prototype of an ergonomic crib, denominated ERGOBERÇO ${ }^{\circledR 1}$. The major aims this prototype was assist the user and attend, considering the roles of the needs their ergonomics, and comfort and safety.

In that sense, the development of ERGOBERÇO ${ }^{\circledR}$ looked for to assist to their users' needs inside of the ergonomic perspective, because, in agreement with Soares (1998 cited by [5]), one of the areas of study of the ergonomics is destined to the consumption products and the relationships that are built during that use, that for the ergonomics should be friendly.

The objective of this study was, to evaluate the prototype of ERGOBERÇO ${ }^{\circledR}$, considering the precepts of the ergonomics of product project, that it seeks to the safety and the users' health directly related to the use, in other words, the child and the one indirect users, for example, parents, or nanny. Specifically, they intended to characterize the direct and indirect users of the prototype ERGOBERÇO ${ }^{\circledR}$; to evaluate the use of the prototype of the crib in loco to understand the user's physical behavior (posture, movements) in the development of the activities; to observe the users' behavior in the use of the prototype during the care with the children; and to identify, in the users' perception, the positive and negative aspects of the prototype during the development of the activity of taking care.

\section{Procedures}

The collection of data was accomplished in the city of Vicosa, state of Minas Gerais, Brazil. The selection criteria for the population were children with age varying between 0 and 2 years old, residents Vicosa, considering for amount that the child still slept in crib at that time of the research. To assist to the objective of the study, they were made 200 phone contacts approximately, and sent letterinvitation to the families with children considering the birth and to institutions of infantile education of

Marks nominative patented by the Group of Ergonomic Planning of the Work - ERGOPLAN/UFV, under the certificate of registration of mark no. 827765720 .
Vicosa, to participate in the study. Of those, they were obtained the return and accept of 50 families and five institutions of infantile education. However, due to some difficulties as reforms in the residences, reduced physical space and illness of some children, considering the short period of time and possibility the residences receive the prototype for test, the sample was composed by 42 children. The evaluations happened from March to May of the year of 2010, in the residences and also in nurseries and day cares, of education institutions infantile, public or matters.

The sample was divided in age groups, to know: 0 to 6 months (10 children), 6 to 12 months (11 children), 12 to 18 months (10 children) and 18 to 24 months (11 children).

After the schedule to realize the meet with the families, considering the accepted to participate in the research, the periodicity of the permanence of the prototype was defined and the prototype stay in each residence for three days. The planning to analyze was: visited for the delivery of the prototype and explanation of doubts regarding the crib and to the evaluation. In the second meet was realized the observations and evaluations of the use of the prototype. They were used to facilitate the observation process the photographic registration and, in other moments, realizing movies about interaction user and crib. The third meet was so that the mother with users evaluated the prototype, using interview considering the themes mother's profile, child and the means and difficulties during the use of ERGO$\mathrm{BERÇO}^{\circledR}$.

\section{Results and Discussion}

\subsection{Evaluation of the prototype of ERGOBERÇO ${ }^{\circledR}$ for the mothers/users}

\subsubsection{The mothers' characterization and users ${ }^{2}$}

In relation to the anthropometric profile, the mothers and users that tested the prototype of ERGOBERÇO $^{\circledR}$ they presented the following characteristics: age varying from 19 to 52 years, height from 1,50 to 1,70 meters and weight from 44 to 89 kilograms.

\footnotetext{
2 It was used the term "users" to distinguish of the mothers the other people that took care of the children, as attends of nurseries and day cares.
} 
Regarding the marital status, the mothers and users presented the following profile: married, $57,14 \%$; unmarried women, 30,95\%; divorced, $7,14 \%$; widows and consecrated, $2,38 \%$ for each category; and 7,14\% didn't inform.

In relation to the professional profile, the following was observed: Home Economics (7,14\%), Infantile Educators (16,67\%), Students (14,28\%), Secretaries $(7,14 \%)$, Housewives $(16,67 \%)$, Forest Engineer $(2,38 \%)$, Teachers $(4,76 \%)$, Management $(4,76 \%)$, Dressmakers $(4,76 \%)$, Cleaners (4,76\%), store box, administrative coordinator, religious person, merchant and public employee; without contract of employment during the period of the research (2,38\%, respectively, for each category). Among the mothers that worked outside of home, $30,95 \%$ stay outside of home for $10 \mathrm{hs}$ (considering the period of 8 a.m until 6 p.m). It was observed that $4,76 \%$ of the mothers exercised work as autonomous, some in night schedule; 33,33\% didn't inform the schedule of the work; and 30,96\% worked in more flexible schedules, in other words, they had autonomy later to begin and finish the work, in some cases the journad of work concluded after to $18 \mathrm{~h}$.

If the parents, especially the mother need, considering the job outside the home family and institutional arrangements were structured for the care with the children. Among those, they can be mentioned: the children were in nurseries and day cares $(45,23 \%)$, with nannies $(9,52 \%)$, with the father $(14,28 \%)$, with the grandmother $(11,9 \%)$, with adult brothers $(4,76 \%)$, with the maid $(2,38 \%)$ or with aunt $(2,38 \%)$ and $9,54 \%$ said that there was never need realize arrangements to care of the child.

\subsubsection{The participant children's of the test of ER- GOBERÇO $O^{\circledR}$ characterization}

Of the 42 participant children of the research, $50 \%$ frequented nurseries or day cares. Age varied between 0 and 24 months of birth, as stipulated by the study, having predominance of some ages as 19 months $(9,52 \%)$ and nine months $(7,14 \%)$.

In relation to the children's anthropometric data, it was obtained the following characterization: as for the height, there was variation between 0,51 and 0,90 meters. The mothers or users didn't know how to inform the height of $38,9 \%$ of the children. In relation to the weight, the values were understood among 4 and 15 kilograms, and $33,33 \%$ of the mothers or users didn't know how to inform the children's weight accurately.

In relation to the hours of sleep, it was verified that the children with up to 12 months of age they slept plus, independently of the period of the day (late or morning). After the 12 months, the period of sleep predominant was after the lunch (afternoon), with $33,33 \%$.

As for the quality of the sleep, $80,96 \%$ of the children slept calm, 11,9\% were agitated sleepy, they were long to sleep, they woke up excessively at night or they lost the sleep. The mothers of 7,14\% of the children didn't know how to inform how their children's sleep was. They said that, so that the children slept, they usually breastfeeded them or they fed them and later they made to sleep them, be in the lap, in the crib or they fell asleep alone, totaling $47,61 \%$ of the observed children. Already $52,39 \%$ used other procedures so that the children slept, among which can be mentioned: to put the child in the chair, in the crib, in the bed or, same, in the lap, so that they could fall asleep alone, hearing music or being sung to sleep.

In what concerns the children's feeding, 23,81\% of the mothers offered to their children some type of milk and common feeding. Among the 42 children of the study, $19,05 \%$ were only breastfeeded with maternal milk; $21,43 \%$ used feeding bottle with modified milk, of several marks found in the market, or pasteurized milk enriched with some type of complement of the farinaceous type or corn starch; $11,9 \%$ already made use of food of salt, for instance soup or home-made food; $9,52 \%$ were breastfeeded with maternal milk and feeding bottle; $9,52 \%$ were breastfeeded with maternal milk and they already fed with food of salt; the others $4,76 \%$ associated maternal milk to the feeding bottle and feeding of salt. For $76,20 \%$ of the mothers, their children didn't present problems of health, for that they considered them healthy; only $14,28 \%$ told to live situations that demanded specific cares and medical attendance. Among the told problems, they can be mentioned: syndrome of Down, reflux, allergy to the bite of insects and some cases of viral illnesses, during the period of the research. The mothers or users $(9,52 \%)$ they didn't know how to inform the children had some problem of health.

\subsubsection{Structures physics of the prototype of ERGO- $B E R C ̧ O^{\circledR}$}


The data obtained in the evaluation of the prototype by the mothers and users about the facility to clean the mothers said the crib used by the child is more easier in relation to the prototype of ERGOBERÇO $^{\circledR}$. The children's mothers in the age group from 12 to 18 months presented the smallest degree of difficulty in the cleaning of the prototype of ERGOBERÇO $^{\circledR}$, with index of approval of $80 \%$. [6] they argued that for a piece of furniture to be considered appropriate he should be of easy cleaning; in that sense, ERGOBERÇO ${ }^{\circledR}$ presented such characteristic.

In relation to the base type, it was noticed the preference by the compact base that composes the prototype of ERGOBERÇO ${ }^{\circledR}$, in reason of that model to offer more comfort, safety and stability, if compared to the base formed by laths, once that piece can offer danger for the child, mother or nanny, besides the risk of damaging the mattress.

The age group understood between 6 and 12 months presented index of approval of $81,81 \%$ for occasion of the evaluation of the compact base. NBR 13918 establishes that, if the base goes of laths, the maximum distance among the laths of the base should be of $6 \mathrm{~cm}$, once superior distance can allow the baby to arrest the leg or the arm. In that sense, the compact base not only it facilitates the cleaning, as well as if it turns safer, because it avoids that accident type. However, there is to consider, also, the subject of ventilation of the mattress provided by the base of laths. The mothers and users suggested, in that case, the placement of holes allow to promote ventilation.

In relation to the appearance, it was noticed certain rejection by the color of the prototype. The mothers and users manifested the preference for clear colors, for example, white color. They also mentioned subjects related to the finish and the viscosity aspect; in relation to the model, they considered rustic. The strip that best evaluated the appearance of the prototype of ERGOBERÇO ${ }^{\circledR}$ was the one from 0 to 06 months, with $80 \%$ of approval. In the aspect appearance, it is believed that the evaluation of the prototype have been differentiate, considering the user's acceptance, case had not been lived the problems during production. Because, during the manufacture of the prototype, it was noticed that the ecoverniz ${ }^{3}$, used for the finish, it was with

As referred them products were open for the laboratorial test, and after open they have useful life of one month information that no available in the packing of the product -, like this, when they were directed for the joinery that produced the yours period of validity expired. That fact generated difficulty for the drying of the surface that received the finish, generating, for consequence, a viscosity, what took to an appearance no appropriate. With that, the furniture was without the protection film against attritions, dusts, powders, dirts, action of the climate and of chemical agents, function that waited to be carried out by the ecoverniz.

Besides the subject previously mentioned, suggestions of improvement of the prototype were presented by their users, among those she can mention: alteration of the dimensions, so that the cradle went larger in the length and in the width. However, the prototype still meets inside of the established dimensions for [1]. The participants of the study still suggested that the prototype should brake in the feet and support for curtains. However, such suggestions need to be very appraised, so that they don't contradict safety's norms for production of crib.

The main differences noticed by the mothers and users, considering the crib of daily use, in relation to ERGOBERÇO $^{\circledR}$, they were the presence of the movable grating, the smaller dimensions (width and length) and larger, the compact base and the headboard and feet also, not being possible to differentiate them referred items. In agreement with [4], holes and high relief in crib can allow the child to arise, as well as tips, edges or any other mechanism that can allow or to facilitate that the child is arrested and is hurt. With that, the choice of the headboard, feet and compact base, without openings, it would avoid that accident and incident type. That is the objective of ERGOBERÇO ${ }^{\circledR}$.

\subsubsection{Evaluation of the safety of the prototype of ERGOBERÇO ${ }^{\circledR}$}

In the evaluation of the prototype for the mothers and users and considering experience with the crib used in daily one, it was possible to evidence that $72,73 \%$ of those pieces of furniture didn't cause embarrassments during the use, as told by those mothers, taking into account the age group from 18 to their babies', that it is the best phase for evaluation of crib 24 months. Those mothers that had difficulties during the use of the cribs told the following:

prototypes, those products were already due (there is little time), but enough to interfere in the final result. The ecoverniz, for instance, lost capacity of instantaneous drying, and the product ended up being with appearance no appropriate (with bad appearance). In that sense, the aspect appearance of the cradles using referred material for finish was committed in the evaluation of the prototype in field. 
presence of corners, space among mattress and lateral of the crib and pains in the backs. In relation to the pains in the backs, [8] they explained that the excessive flexing of the trunk makes possible the distance between the individual and the child and, with that, it increases the lumbar effort, resulting in the contraction of the mother's number musculature, in other words, causing pains in the backs. Those authors increased that you level fixed in the cradle they provoke problems, once they impede the flexing of the articulations of the inferior members (hip, knees and ankles). The mothers and users also told cases of the child's of the crib fall and that the model that used presented space between the mattress and the crib, what could do that the child was hurt. On that subject, [4] it recommends that, to avoid that the child is hurt arresting legs and arms, the distance recommended between the base and the lateral ones or walls of the crib should not be superior to $2,5 \mathrm{~cm}$.

In relation to the classification of the danger of accidents offered by the cribs of daily use, in comparison with the prototype of ERGOBERÇO ${ }^{\circledR}, 80 \%$ of the mothers and users with children in the age groups understand-give between 0 and 6 and 12 and 18 months classified as of bass or any danger. Regarding the classification of accident danger involving the prototype of ERGOBERÇO ${ }^{\circledR}$, again they stood out the strips previously mentioned with $100 \%$ of the mothers and users considering the prototype of ERGOBERÇO ${ }^{\circledR}$ as of bass or any accident danger for the child.

The mothers' concern and users were basically with the fact of the prototype to be loud and the movable grating to come unfastened case the child it forced her. That situation was witnessed in one of the visits, when it was witnessed a child's of one year scene and five months balancing the movable grating and being hung in her and piece if it didn't loosen. With that, it is believed that the possibility of the grating to unlock it is remote. For [4], the grating piece of furniture cannot allow the child to arrest any part of the body and that the maximum height should be of $30 \mathrm{~cm}$ and the low of $22,8 \mathrm{~cm}$, situations those when the mother is putting and removing the baby of the crib.

In the requirement spacing among the bars that compose the grating of the crib, $90,91 \%$ of the mothers and users affirmed that never accidents related to the spacing happened, considering the age group from 18 to 24 months. One of the participant mothers of the research told that, before buying the crib, researched on the appropriate spacing among the grating and, for that, there were not accidents involving the child. Such fact reinforces what mentioned [2] in study, in which was noticed increase of the parents' concern with the children's safety, considering the infantile furniture, once you fail can result in sharp pieces of furniture, cutting parts and, with that, to cause accidents.

In what refers to the intoxication for ingestion of parts of the crib, the study revealed that, independently of the age group, there was not any case of intoxication. However, some mothers told that their children bit the superior bar of the crib, getting to remove the plastic of protection of the wood. In that sense, [7] concern is reinforced, that it emphasized the need to use material non toxic to protect the child's physical integrity, once the baby uses the crib or any other object, in certain phases of development, to bite or to scratch the teeth, being exposed to possible chemical and physical agents existent in the piece of furniture.

It can be affirmed, for the mentioned data, that ERGOBERCO $^{\circledR}$ in the mothers' evaluation and users is safe, offers less danger to the child and them same while indirect users of that furniture.

\subsubsection{Evaluation of the comfort of the prototype of ERGOBERÇO ${ }^{\circledR}$}

The data revealed that $81,82 \%$ of the mothers and users with children in the strip from 18 to 24 months didn't feel discomfort during use. However, 45,45\% of the mothers and users with children in the strip from 0 to 6 and 6 to 12 months were what more demonstrated discomfort during the use of that crib. They emphasized to have forced the column in the moment which retreat of the child's of the prototype. [8], says as the child grows, weight also increases, demanding more effort of the parents, being the movable grating an option to aid in that process of to put and to remove the child of the crib with more safety and comfort.

The prototype was also considered narrow and heavy, and that contributed so that the interviewees considered little space for the children if they move.

In relation to the height of the prototype, $80 \%$ of the mothers and users didn't tell difficulties, being considered the age groups from 0 to 6 months, from 12 to 18 months and from 18 to 24 months. In that aspect, the action was observed of to put and to remove the child of the interior of the prototype of ERGOBERÇO $^{\circledR}$. However, 36,36\% demonstrated difficulties in that activity, being considered the age 
group from 6 to 12 months. Such discomforts, which are: to remove or to put the child inside the prototype, they were due to the fact of they consider loud and they always use the prototype with the movable grating in the highest position. Souza and Merino[8] suggested the use of the movable grating as form of aid in the child's manipulation, besides to reduce the damages on the column. In the study in subject, the mothers and users pointed the use of the movable grating as positive characteristic for the prototype, to facilitate the use of the product.

The possible tunings of height of the base were considered more appropriate for the mothers and users with children in the age group from 0 to 6 months, with $90 \%$ of approval. The mothers and users with children in the age group from 12 to 18 months were the ones that manifested smaller acceptance regarding that aspect ( $60 \%$ of approval). In the general, for the mothers and users was enough to choose the height in agreement with the child's size, what is reinforced by [8], because, for them, with the increase of the age and of the weight of their child movements they are also going intensifying and, the minimum height of the base is more appropriate to bigger children and, the maximum height, for children smaller, and newly born, that are lighter and they are moved less.

During the use of the prototype, the sleep was considered calmer for the mothers and users with children in the age group from 0 to 6 months, with $90 \%$ of approval. Already in relation to the quality of the children's sleep in the prototype of ERGOBERÇO $^{\circledR}$ was possible to notice that the mothers and users with children in the age group from 12 to 18 months were the ones that considered that the product didn't contribute to a calm sleep of the son, in $30 \%$ of the cases.

The mothers and users with children in the age group from 18 to 24 months were what best evaluated the prototype of ERGOBERÇO ${ }^{\circledR}$ concerning the children's movement inside the crib the use is easiness, and the prototype got $100 \%$ of approval. But with mothers and users with children 6 to 12 months considered less appropriate, because child got moves freely and with safety in interior, in $27 \%$ of the cases.

As for the use easiness and satisfaction with the prototype of ERGOBERÇO ${ }^{\circledR}$, the mothers and users with children in the age group from 6 to 12 months were the ones that considered more difficult use $(18,18 \%)$ they took about the weight, displacement, the mechanism of tuning of the movable grating and the change of height of the base. The [1] recommends that, for bases with adjustable heights, is necessary that height change is made with the tool aid or substitution of the fitting, and that does that the risk of accidents is minimized, therefore it avoids that the base changes of alone position. In that sense, same being a point on which the mothers and users complained, it was noticed that is a important point for the prototype to be a safe furniture, in other words, that it presents difficulty for change of position of the grating during the use, to treat of element of safety of that furniture.

Considering the previous data, it can be said that, in general, the evaluation of the prototype of ER$\mathrm{GOBERÇO}^{\circledR}$ was positive in what refers to the use and comfort provided by the piece of furniture. The age group from 18 to 24 months stood out in the evaluation of the prototype of ERGOBERÇO ${ }^{\circledR}$, attributing good evaluation in four variables (indisposition/uncomfortable, height/large, free movement and use and comfort) of the appraised six (indisposition/uncomfortable, height/large, position/height of the base, sleep quality of the child's, free movement, use and comfort). It is believed that that happened in reason of, in that development phase, the child already to be if socializing in a more intense way with the atmosphere, being possible, in that way, to notice those mothers' positive and negative reactions better in relation to the interaction with the product in daily one. However, the child, of up to six months of age, it stays more time in the crib and it is also moved low, it explores less the furniture and, like this, the evaluation for the mothers and users with children in that age group was also of plenty acceptance, except in the first variable, which is, indisposition or uncomfortable, the too much was above $80 \%$.

It can be observed that, except for the variable indisposition/uncomfortable presented by the prototype of ERGOBERÇO ${ }^{\circledR}$, the others obtained values relatively low, allowing to infer that, in relation to the use of the prototype, this offered good interface with the user, what facilitated positive evaluation and, consequently, the acceptance of the product.

Come the notes attributed by the mothers and users to the prototype of ERGOBERÇO ${ }^{\circledR}$ in relation to the use and comfort provided. For that subject, the mothers and users could attribute notes from 1 until 10 to that prototype. However, the notes varied between 5 and 10. 
It is noticed that the age group that attributed smaller note to the prototype of ERGOBERÇO ${ }^{\circledR}$ (note 5) it was her acted by the mothers and users with children from 6 to 12 months $(9,09 \%)$. The age group that best evaluated the prototype of ERGO$\mathrm{BERÇO}^{\circledR}$ (note 10) it was that acted by the mothers and users with children from 12 to 18 months, in $50 \%$ of the cases. The note 8 also stood out in the mothers' evaluation and users with children in the age groups from 6 to 12 and 18 to 24 months, with $45,45 \%$.

\section{Conclusions}

The prototype can be considered a furniture, which in relation the physical structure, proposed alternatives to avoid accidents during the use, about this the study can mention: the compact base that was preferred by their characteristics of stability, safety and comfort and for offering less damage risk to the mattress. In spite of some participants of the research they have emphasized that the base of laths allows to ventilation to the mattress, characteristic that non present in the compact base, this was considered of easy cleaning and safer to the child. It was suggested that the compact base had holes to permit to allow the circulation of air wanted for the mattress, maintaining, with that, the positive characteristic of the base, which is, to be compact and to give stability to the mattress during the use of the crib for the child.

The movable grating was also pointed as some of the characteristics that more pleased the volunteers of the study, as interesting and efficient form to help the parents and other user to handle the children and to avoid positions to come to demand effort the column, considering the load movement.

For the aspect appearance of the prototype ERGOBERÇO $^{\circledR}$, the non acceptance was more focused in the user, considering facility for cleaning. It was noticed that the mothers and users prefer white infantile furniture, showing the importance of the aesthetic aspect for acceptance of the product for the parents, being the variable used to define the choice of their children's crib.

ERGOBERÇO $^{\circledR}$ was considered more safer than the mothers' cribs. That result happened in function of the presence of the movable grating, of the height of the prototype and of the spacing among the grating. It can be said that, in relation to the comfort aspects and use easiness, the prototype assisted, in a considerable way, to the users' needs.

In relation to the different evaluations among the age groups, it was noticed that were related with each user's needs and with the form as each one used the furniture. The crib served more as rest place for the baby/child, as well as the atmosphere where the child had to play. In that last case, the child stayed more time in the furniture and the possibility of accidents increased and, like this comfort demands and safety is necessary.

All considering the mentioned aspects, it is believed that the prototype needs to pass for modifications/restructurings, to example of adaptation to the project idealized in relation to their dimensions, and to join the aspects stood out by the users, for the piece of furniture it can approach the needs and the final user's demands more and more and to be considered as appropriate product to the use, being considered all the variables to structure the prototype, besides the ones that would user the aesthetic attribute.

\section{Acknowledgement}

This research receives the financial support of FAPEMIG (Foundation of Help to the Research in the State of Minas Gerais).

\section{References}

[1] ASSOCIAÇÃO BRASILEIRA DE NORMAS TÉCNICAS. NBR 13918:2000 - Móveis - Berços Infantis - Requisitos de segurança e métodos de ensaio, aspectos importantes. 2000 .

[2] FERREIRA, A. R. Utilização do design na gestão da qualidade: Uma mudança de paradigmas no Setor Moveleiro de Santa Maria - RS. 2008. 95 f. Dissertação (Mestrado em Engenharia de Produção) - Universidade Federal de Santa Maria, Santa Maria, RS, 2008.

[3] FIALHO, J. F.; MAFRA, S. C. T. Análise ergonômica da segurança e adequabilidade de berços para crianças de 0 a 2 anos. 2005. 54 f. Relatório Técnico (Pesquisa de Iniciação Científica, PIBIC/FAPEMIG) - Universidade Federal de Viçosa, Viçosa, MG, 2005.

[4] INSTITUTO NACIONAL DE METROLOGIA, NORMALIZAÇÃO E QUALIDADE INDUSTRIAL INMETRO. Relatório sobre análise em berços infantis. Rio de Janeiro: Ministério do Desenvolvimento, Indústria e Comércio Exterior, 2007. Available on: $<$ http://www.inmetro.gov.br/consumidor/produtos/berco.pdf >. Acess on: 19 jul. 2010.

[5] LAUTENSCHLÃGER, B. I. Avaliação da embalagem de consumo com base nos requisitos ergonômicos e informacionais. 2001. 109 f. Dissertação (Mestrado em 
Engenharia de Produção) - Universidade Federal de Santa Catarina, Florianópolis, 2001.

[6] LIMA, A. L. S.; BENATTI, L. P. Estudo das principais falhas do mercado de mobiliário brasileiro com foco no mobiliário infantil. In: ENCUENTRO LATINOAMERICANO DE DISEÑO, 4., 2007, Buenos Aires. Actas de Diseño... Buenos Aires, 2007.

[7] SILVA, V. L. S. Descrição evolutiva do comportamento exploratório-manipulativo na criança nos primeiros dois anos: Uma Revisão Bibliográfica. Psicologia: Ciência e Profissão, n. 1, p. 51-75, 1982. Available on: $<$ http://pepsic.bvs-psi.org.br/pdf/pcp/v3n1/02.pdf >. Acess on: 5 jul. 2009.
[8] SOUZA, J.; MERINO, E. Contribuição da ergonomia na avaliação do mobiliário infantil (berço). In: CONGRESSO LATINO AMERICANO DE ERGONOMIA, 7.; CONGRESSO BRASILEIRO DE ERGONOMIA, 12.; SEMINÁRIO BRASILEIRO DE ACESSIBILIDADE INTEGRAL - Ensino, Pesquisa, Certificação e Ação Ergonômica, 1., 2002, Recife. Anais... Recife: ABERGO, 2002. p. $1-6$. 